\title{
PUBLIC SECTOR - CONCEPTUAL ELEMENTS, IMPLICATIONS IN ECONOMIC AND SOCIAL LIFE*
}

\author{
Florina Popa \\ Institute of National Economy, Romanian Academy \\ florinapopa@gmail.com
}

\begin{abstract}
The public economy, branch of economic science analyses the state, as economic actor; its field of research interacts with investigations of other areas of economic science (monetary, international trade, market organization etc.). The state has experienced various stages of manifestation of its role in the economy, against the changes in society, which led to either an increase in its intervention, to regulate market phenomena, the recovery of economic activity in times of crisis, or to its decline against the modernization of the economies of industrialized countries, the increase of the role of entrepreneurs, technological progress. Thus, the development of economic science, changes in economic area, the emergence of capitalism, of industrialization in the nineteenth century, especially the second half, outlined a new role towards state intervention in economic life; in the context of new economic developments of the last decades of the twentieth century, the interventionist role of the state has diminished, the state giving up certain activities, in return for initiating other actions (privatization, reducing state monopoly, deregulation).The paper presents conceptual elements referring to public sector, peculiarities that distinguish it from the private sector, as well as issues about the state implication in the economic life, in different periods of evolution of society.
\end{abstract}

\section{Keywords}

public economy; institutions; private sector; state implication

\section{JEL Classification}

H11; P43

\section{Introduction}

The entire human existence is inseparably linked to the presence of the state, to the activities that it develops manifested in many fields of the economic and social life.

State's interventions, as an economic actor, take the form of services provided to the community (in areas that cannot be covered by the private sector), of the economic, legal regulations, in order to correct the deficiencies of the market economy, or destined for stimulating the economic activity.

State's political decisions determine the system of rules based on which the society operates, namely, political, economic, legal institutions, essential for the life and actions of individuals.

Government's action provide to the community's individuals several advantages in matters which mark their material and spiritual existence: ensuring ownership (individual and joint), reducing transaction costs, etc.

\section{The public sector - theoretical elements}

The scope of the concept of economy includes a series of categories in various areas: public, services, political, social, investment, other branches.

\footnotetext{
*Acknowledgment. The study is a part of the research paper of the Institute of National Economy, Romanian Academy - „Criterii de eficienţă economică şi socială a administraţiei publice din România” - achieved in 2016, by a team of researchers - Dr. Daniela Antonescu (coordinator), Florina Popa.
} 
References on the concept of economy have been made since ancient times, starting from Xenophon and Aristotle in Ancient Greece, or Seneca, Pliny the Younger and Elder in Ancient Rome, as they developed conceptions about how to make wealth from agriculture, from livestock.

For classical economists (Adam Smith, David Ricardo), economics is a science of wealth, which is based on production, its growth being conditional on productive level; in case of neoclassic writers (Hayek), the exchange process, by the price level (as the supply-demand ratio) is decisive for achieving wealth.

In the modern era, economics is a science of allocating the goods, the resources which are limited, given an unlimited demand.

As a branch of economics, public economics is to study the action of the state, its role in the economy of a nation.

The main function of public sector economy is to capture the significance of the public sector concept in the development of economic phenomena, to motivate the need for the presence of this sector in the economy, through the institutional system created, following the allocation of resources at the state level, its degree of involvement in economy.

Public economics, a branch of economic science analyses the state as economic actor, its scope of research interacting with the investigations of other areas of economics, such as the monetary, international trade, market organization field, etc..

Among the definitions given by specialists in this field of economics, public economics, we can mention:

- "it is a branch of economics that focuses on analysing the role and behaviour of the State $[. .$.$] and on its impact on the national economy and even on the international one,$ and consequently, on the welfare of citizens" (Profiroiu et al, 2011).

- the "expression - public sector - means the set of economic or social activities carried out under the total or partial control of the state and local communities. It is opposite to that of the private sector " ("Toupictionnaire": le dictionnaire de politique. Secteur public, http://www.toupie.org/Dictionnaire/Secteur_public.htm).

- "represents a component of economics which specializes in the study of the separation of the public sector activities, the understanding of the consequences of this activity, as well as of possible alternatives, tools and methodology specific to the economy, namely focusing on analyzing the effectiveness of public resource allocation, the cost -benefit analysis of state activity" (Ailenei, 2005).

- as a branch of economics, the public sector economics studies the area of action of the government, analyzing the government functions in the society, focusing on how it allocates resources, as well as on its composition (education, health etc.) (Marinescu).

From all these definitions, emerges the basic idea that this branch of economics is to study public sector policies (of the state) oriented towards development and welfare.

In the area of the public sector economics analysis there is a number of categories of activities regarding: services provided to community, state regulations destined to increase welfare policies, policies to encourage economic growth, funding, resources, their distribution.

A distinctive feature of the public sector in relation to the private one is the authority of decision making, which determines the characteristics and mode of operation of the two systems: the public sector and market economy.

- The market economy system- the decision making has a decentralized character, which assumes:

$\Rightarrow$ The object of exchange - the property rights of the owner of the goods and services provided;

$\Rightarrow$ The exchange - voluntary, mutually beneficial for the parties under market relations;

$\Rightarrow$ Economic operators decide what they use, generate or consume, as appropriate, wanting to obtain the satisfaction at the expected level; 
$\Rightarrow$ The demand-supply balance is determined by pricing the goods / services on the corresponding market.

- The public system - the decision making is centralized - the decision is political, the principle on which the system is based is the existence of a coordination authority that orders economic agents the way in which they participate in economic life:

$\Rightarrow$ the limits allowed to consumers to purchase goods and services;

$\Rightarrow$ the categories of goods that can be delivered by producers;

$\Rightarrow$ the resources established;

$\Rightarrow$ the authority of decision is the holder of resources, establishing their destination.

Even with the restrictions that the system imposes, public policies are, also, the object of demand (citizens) and of supply (central, local government) (Profiroiu, A., Profiroiu, M., 2007) $)^{1}$.

\subsection{The State, a presence in economic life}

The state is a political category closely linked to the economy. There are several reasons that outline the concept of State:

"... the State includes the territory, population and organized state power. In this case, it is considered that the state is a human group set within a given territory over which a sovereign public authority is exercised" (Năstase, Mihăilescu, 2008).

From a sociological perspective, the state is "a specific and essential dimension of political society, a society that resulted from the settling on a particular territory, of a human collectivity, relatively homogeneous, embodying the nation and which is governed by an institutionalized power, with the ability and means to express and to carry out the will of a part of the community, as general will. This will can belong, in concrete historical conditions, to a small group or to a majority group" (Manescu, 2014).

From the organizational perspective, the state is "a set of regulatory and governance institutions, which are designed to produce rules, to control, to direct, or regulate" (Profiroiu et al, 2011).

Related to the functional aspect, on the one hand, the state refers to the set of institutions the objectives of which correspond to state's functions and on the other hand to the effects that institutions and its functions produce, regarding the social order, the economic and social stability, the insurance of welfare, etc..

In this sense, the State shall establish and implement policies depending on the effects pursued. Thus, some categories of state intervention can be exemplified, the expression of its involvement in the economy:

- creating an economic, social legal framework, protecting and defending the moral, cultural traditions of the national territory;

- getting involved in the mechanisms of life by regulatory measures in order to increase economic performance.

In relation to the dimensions of state involvement, the economic and social organizational arrangements meet the type of state (liberal, neoliberal, bureaucratic).

From an economic perspective, the public sector (the state) is considered "the production system of public goods and services" which includes the process of formation of demand and supply for this product category and the related institutional system (public decision, public property). In the representation of economic actor, the

\footnotetext{
${ }^{1}$ In contemporary economy, it cannot make strict delimitations on how resource are allocated, respectively, between the public and private sector, the elements and mechanisms of the two systems - based on the principle of decentralization, respectively of centralism, interacting and acting as a mixed economic system (free market system combined with state intervention). Real economic system - mixed - modern market economy system - is characterized by the existence, in varying degrees, of the elements which manifest itself in two forms, with a preponderance, however, of the market ones.
} 
public sector (state) is defined as "the set of all activities developed by the State", which includes the following bodies (Profiroiu et al, 2011):

- Public institutions the resources of which come from the public budget:

- central and local governments producing public goods and services aimed for the society. Powers of decision in achieving public interests, on administrative levels central, local, regional - are granted in relation to the existing decentralization degree, to the political decision;

- social protection bodies answerable to the public power and its decisions;

- Public enterprises obtaining income (resources) from the sale of own production, namely:

- autonomous administrations, national companies (without the competition of private companies);

- joint ventures with state-owned and private capital (belong to the public sector but the operation manner is similar to the private sector). They compete with the private sector; - banks and insurance companies with public capital.

There is no clear demarcation between the public and private sector, as they are related and competing, the line separating them continuously moves, according to political orientation.

Both the public and private sectors are distinguished by features in opposition (Table 1).

Table 1 Features that distinguish the public sector from the private sector

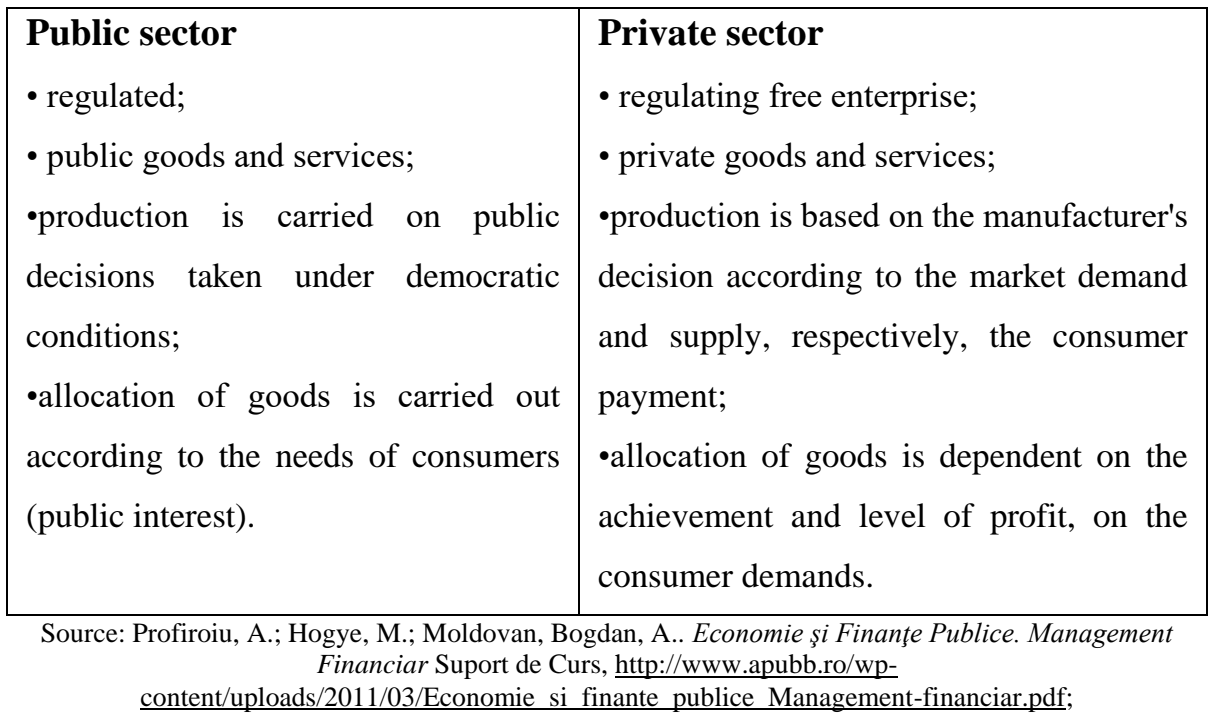

Thus, for the optimal allocation of resources, the public sector plays a major role, through the influence that governmental activities exert on it, respectively, the level of public expenditure reflected on the society.

\subsection{The evolution, in time, of the state in the economy}

The manifestation of the position and of the activities of the state in the economy has been a topic of different views of economists favourable, as necessary, to a neutral state or to an interventionist state, significantly involved in the society's life. 
In early nineteenth century the classical liberal doctrine, launched by A. Smith, limited government interference, the government assuming the exercise of responsibilities on limited, traditional areas (national security, justice, education). The market served as self-regulator under free trade and competition and also as distributor of resources.

The development of economics, changes in economic field, through the emergence of capitalism, of industrialization in the nineteenth century, especially in the second half, had given a new role to the state in economic life. The need to promote a fair competition, to balance economic activities, protection of consumers, motivated state's intervention in the promotion of fair competition based on free enterprise, on free movement of capital, of labour, on the manifestation of demand and supply on the market which would ensure pricing.

The events of early last century, the development of microeconomics, the First World War, the economic crisis in the twenties had brought about change in the traditional approach and increasing the government's role in solving national economy problems. The state had to intervene through taxes, subsidies to finance goods and services which were not provided through the market.

According to Keynes, the phenomenon of self-regulation of the market does not ensure the optimum allocation and in case of unstable economies, the system favours the increase in unemployment, which implies for the state, the task of becoming a more active factor in economic life, serving to correct market errors, which assumes, also, increasing expenditure volume.

Performance of the state in the economic range rose in the period between the two world wars, emphasizing interventionism after the Second World War when the scope of the public power increased.

Through public enterprises, the state became a producer, consumer, employer, exercising the main functions of allocation, stabilization, redistribution.

The manifestation of the "welfare state" aimed at social solidarity represented a development of economy capable of ensuring social protection, including public actions for the benefit of citizens, accompanied by corresponding increased public expenditure, and effects in tax increases.

In the last decades of the twentieth century, in the context of imperatives emerging in industrialized countries, of modernizing economies (increased role of entrepreneurs, of technological progress) the significance of the interventionist state decreased, which gave up certain activities in exchange for initiating other actions; they proceeded to the privatization of the public sector in various fields, they gave up the state monopoly, the deregulation process took place.

The increasing role of the state in the economic and social field was manifested after the financial crisis peak in 2008-2010, the state organizing interventions to redress through actions destined to support economic activity (injections of liquidity and saving banks or companies from bankruptcy).

Given the rapid changes occurring in the environment where traders move, it is expected for the state to develop a strategy of perspective and supervision of the future, which involves financing the expenditure that is usually borne by the public sector, and also support for private initiatives.

At the same time, there are uncertainties about the effectiveness of public actions, the probability of the risk of occurrence of state failure being linked to the inefficient side of public sector bureaucracy and to the costs that it engages, to the difficulty and complexity of solving tasks that belong to the public sector. The aspect involves the need for clear delimitation of government actions that would ensure the most advantageous alternative to the degree of state intervention in the market economy. 


\section{Conclusions}

The main function of the public sector economy is to capture the significance of the public sector concept in the development of economic phenomena, to motivate the need for the presence of this sector in the economy, by means of the institutional system created, following the allocation of resources at state level, the degree of its involvement in the economy.

Public economics, a branch of economic science analyzes the state as an economic actor, its implications being manifested in the economic life through a series of actions that include the legal regulations for carrying out the social and economic life, the interventions in the market mechanism through reforms designed to increase economic performance, however, in the context of the links that the public sector provides between the sphere of production and consumption and the carrying out of economic flows between economic operators.

Given the rapid changes occurring in the environment where economic agents are moving, it is expected for the state to develop strategies of perspective and supervision of the future, which assumes financing the expenditure which is usually borne by the public sector, and also support granted for private initiatives.

\section{References}

Ailenei, D.

(2005),

Economia

sectorului

public, http://www.documents.tips/documents/economia-sectorului-

public.html; http://www.ase.ro/biblioteca/.

Ailenei, D. (2002), Economia sectorului public, Bucuresti, Bren.

Ailenei D., Grosu T., Economia sectorului public, http://www.bibliotecadigitala.ase.ro/biblioteca/carte2.asp?id=389\&idb.

ASE Catedra de Economie Politică colectiv de coordonare: Dobrotă N., Ciucur D., Coşea M., Enache C., Gavrilă I., Tănase Paul G., Gogoneaţă C., Popescu C. (1995), Economia politică, ASE, Bucureşti, Editura Economică.

Dobrotă, N. (1997), Economie politică, Bucureşti, Editura Economică.

Dobrotă, N. (coordonator) (1999), Dicţionar de economie, Bucureşti, Editura Economică.

Généreaux, J. (2003), Les Trois Fonctions de l'Etat, selon Richard Musgrave, Alternatives Economiques, No. 219, 01/11/2003, http://www.alternativeseconomiques.fr/trois-fonctions-de-letat-selon-richard-musgrave/00027793.

Ionescu, C. (2007). Instituţii politice şi drept constituţional, Bucureşti, Editura Universitară.

Keynes, John, M. (1970), Teoria generală a folosirii mâinii de lucru, a dobânzii şi a banilor, Bucureşti, Editura Ştiinţifică.

Lazăr, D., Inceu, A. (2000), Administraţie publică, Cluj-Napoca, Accent.

Marinescu C. Economia sectorului public. Note de curs, http://www.cse.uaic.ro/fisiere/Documentare/Suporturi_curs/III_Economia_se ctorului_public.pdf.

Marinescu C. (2004), Instituţii şi prosperitate. De la etică la eficienţă, Editura Economică, Bucureşti.

Mănescu, N. (2014), Statul - Concept şi Elemente Constitutive (The State - Concept and Constitutive Elements), Analele Universităţii "Constantin Brâncuşi" din Târgu Jiu, Seria Ştiinţe Juridice, Nr. 2/2014, Editura „Academica Brâncuşi”" (Annals of the ,C Constantin Brâncuşi ”, University of Târgu Jiu Juridical Sciences 
Series ISSUE 2/2014 „Academica Brâncuşi” Publisher), pp. 83-96, http://www.utgjiu.ro/revista/jur/pdf/2014-02/08 Nicolae\%20Manescu.pdf.

Mihaiu, Diana, M., Opreana, A., Cristescu, Marian, P. (2010). Efficiency, Effectiveness and Performance of the Public Sector, Romanian Journal of Economic Forecasting 4/2010, pp. 132-147, http://www.ipe.ro/rjef/rjef4_10/rjef4_10_10.pdf. https://www.ideas.repec.org/a/rjr/romjef/vy2010i4p132-147.html;

Năstase, Georgescu, M., Mihăilescu, Simona, Th., L. (2008), Drept constituţional şi instituţii politice - Curs universitar, Editura Moroşan.

Profiroiu, A., Hogye, M., Moldovan, Bogdan, A., (2011), Economie şi Finanţe Publice. Management Financiar Suport de Curs, http://www.apubb.ro/wpcontent/uploads/2011/03/Economie si finante publice Managementfinanciar.pdf.

Profiroiu, M. (2001), Managementul organizaţiilor publice, Bucureşti, Editura Economică.

Profiroiu, M., Profiroiu A. (2005), Modul V Administraţie Publică şi Integrare Europeană, pp. 574-670, în Management Public Verboncu Ion (coordonator), et. al.Bucureşti, Editura Universitară.

Profiroiu, A., Profiroiu, M. (2007), Cadrul de analiză a performanţelor sectorului public, (Analysis of Public Sector Performance), Economie Teoretică şi Aplicată, (Theoretical and Applied Economics), nr. 1/2007, pp. 41 - 50, http://www.ectap.ro/analysis-of-public-sector-performances-alinaprofiroiu_marius-profiroiu/a180/.

Profiroiu A., Profiroiu M. (2007), Autonomia financiară a colectivităţilor locale din România - Premisă a succesului descentralizării, Transylvanian Review of Administrative $\quad$ Sciences, 19/2007, pp. 77-85, http://www.rtsa.ro/rtsa/index.php/rtsa/article/viewFile/163/159.

Ready, B., Chapitre 2 L'Allocation des Ressources, https://www.scribd.com/document/249295987/Chapitre-2-L-Allocation-Des-

Ressources.

Ricardo, D. (1821), The Principles of Political Economy and Taxation, The Electric Book Company Ltd, http://virtualpanic.com/anonymousftplistings/ebooks/ECONOMICS/Principles \%20of\%20Political\%20Economy\%20and\%20Taxation,\%202006..pdf.

Sandye, Gloria-Palermo. Cours d'Economie Publique, Master 1 Sciences économiques, Année universitaire 2006-2007, http://calamar.univag.fr/palermo/cours/Cours\%20d'\%E9conomie\%20publique.htm.

Smith, A. (1965), Avuţia naţiunilor. Cercetare asupra naturii şi cauzelor ei, Bucureşti, Academia Republicii Populare Române.

Văcărel, Iulian (coordonator); Anghelache, Gabriela, Bercea, Florian, Bistriceanu, Gh., D., Bodnar, Maria, Moşteanu, Tatiana, Georgescu, Florin, (2005), Finanţe publice, ediţia a cincea, Bucureşti, Ed. Didactică şi Pedagogică.

Veiss, Sorina,D. (2012), Eficienţa şi eficacitatea în sectorul public (Efficiency and effectiveness in public sector), REGENT, Volumul 13, Nr.3/November 2012, pp. 368-378, http://www.recentonline.ro/036/Veiss D-R36.pdf;

Verboncu, Ion (coordonator) et. al. (2005), Management Public, Editura Universitară, Bucureşti;

Vezure, Oana, S., (2011), Funcţiile Finanţelor Publice (Public Finance Functions), Analele Universităţii "Constantin Brâncuşi” din Târgu Jiu, Seria Economie, Nr.3./2011, pag. 221-231, http://www.utgjiu.ro/revista/ec/pdf/201103/28_OANA_SABINA_VEZURE.pdf; 
Von Hayek, Frederick, A. (1937), Economics and Knowledge, Economica, New Series, Vol. 4, No. 13 (Feb.1937), pp. 33-54, http://www.jstor.org/stable/i343614;

Zai, P., Lazăr, D., Inceu, A. (2012), Economie şi finanţe publice Universitatea BabeşBolyai, Cluj Napoca, Facultatea de Ştiinţe Politice, Administrative şi ale Comunicării, Cluj-Napoca, www.fspac.ubbcluj.ro/moodle/pluginfile.../curs\%20ec\%20si\%20finante\%20pu blice.pdf;

"Toupictionnaire": le dictionnaire de politique, Secteur public, http://www.toupie.org/Dictionnaire/Secteur_public.htm;

Vie Publique. Au coeur du débat public Publié le 5 février 2015 par ERASME, http://www.vie-publique.fr/spip.php?page=reperes;

Vie Publique. Au coeur du débat public Découverts des institutions. Le role economique de l'Etat, Approfondissements, 30.05.2006, http://www.viepublique.fr/decouverte-institutions/finances-

publiques/approfondissements/role-economique-etat.html 